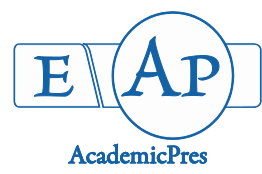

\title{
Odonata Recorded in the Buffer Zone of Mt. Hamiguitan Range Wildlife Sanctuary with Remarks on the Distribution of Endangered Risiocnemis antoniae in Davao Oriental Philippines
}

\author{
Milton Norman D. MEDINA ${ }^{1 *}$, Analyn A. CABRAS ${ }^{2}$, \\ Reagan Joseph T. VILLANUEVA ${ }^{3}$, Ruel COLONG ${ }^{4}$ \\ ${ }^{1}$ University of Mindanao, Institute for Biodiversity and Environment, Research and Publication Center, Matina, Davao City, \\ Philippines; mnd_medina@umindanao.edu.ph (*correspondingauthor) \\ ${ }^{2}$ University of Mindanao, Math and Science Department, Matina, Davao City, Philippines; ann.cabras24@umindanao.edu.ph \\ ${ }^{3}$ D3CGahol Apartment, Lopez Jaena St., Davao City, 8000, Philippines; rjtvillanueva@gmail.com \\ ${ }^{4}$ Office of the PASu, Government Center, San Isidro, Davao Oriental, Philippines; ruelcolong@gmail.com
}

\begin{abstract}
Mt. Hamiguitan Range Wildlife Sanctuary is both a UNESCO and ASEAN recognised heritage site. There is a current move to expand the site by expanding the buffer zone. This area unfortunately is poorly studied in terms of its biodiversity. This paper explores the odonata species found in the proposed buffer zone. Transect line along fluvial ecosystem was established in the two bordering municipalities. A total of 32 species from 22 genera and nine families were recorded in which eighteen species (18) belong to the suborder Zygoptera while 14 species are Anisoptera. High level of endemism was recorded for Zygoptera (94.44\%) endemism while low endemism for Anisoptera (21.43\%). Distribution of Risiocnemis antoniea (Gassmann and Hämäläinen, 2002), an IUCN endangered damselfly was recorded in the creeks of Barangay Tandang Sora, Governor Generoso at relatively lower elevation between 100-300 meters above sea level. Due to its habitat's close proximity to human habitation and the encroaching anthropogenic disturbances, it should be declared as Local Conservation Area.
\end{abstract}

Keywords: Buffer Zone; Davao Oriental; Odonata; Philippines; survey

Abbreviations: MHRWS: Mt. Hamiguitan Range Wildlife Sanctuary; EMBC: Eastern Mindanao Biodiversity Corridor

\section{Introduction}

Odonata is one of the most primitive insect groups in the world that dominates aquatic ecosystems (Grimaldi and Engel, 2005). They play pivotal role in the ecosystem as pest control, water quality and habitat bio-indicator and can be used in monitoring anthropogenic disturbances (Samway et al., 2010; Medina et al., 2016). They are found in both standing and running water with few species being able to withstand brackish water (Kalkman, 2008). Although they are found in almost all types of aquatic habitats there are several habitat specific species (Silva et al., 2010). Majority of the rare and endemic species are associated with undisturbed and intact forests with good water quality (Gapud, 2005). Globally, there are 5,680 extant species with the tropics having the greatest diversity and numbers of species approximately about 1,500 (Kalkman, 2008).

The Philippines is a tropical country that belongs to one of the mega-diverse countries in the world contributing a significant number of flora and fauna to world's total biodiversity (Convention on Biological Diversity, 2009). However due to the unprecedented habitat loss, it is also considered as one of the hottest of hotspots and is considered as a top priority for conservation (Myers et al., 2000). The Philippine Odonata has about 300 recorded species which is characterized by a very high level of endemism- $90 \%$ for the Zygopterans and $40 \%$ for the Anisopterans (Hamalainen, 2004; Gapud, 2005). Despite the high level of endemism and the threats to the endemic species, very few species have been assessed by the IUCN thus only few species were considered as threatened. Among the threatened Odonatais the critically endangered Risiocnemis antoniea which is exclusively found in Eastern Mindanao (Gassman and Hamalainen, 2002; Hamalainen, 2004).

Mindanao, the second largest island in the country, with a total of $97,530 \mathrm{~km}^{2}$ is a home to more than 130 species of Odonata (Hamalainen, 2004). Mindanao's rugged topography of volcanic mountains also prides in the presence of Mt. Hamiguitan Range Wildlife Sanctuary (MHRWS) which is both an ASEAN and UNESCO biodiversity heritage park (UNESCO, 2014). It forms part 
of the mountain range along Pujada Peninsula in the Southeastern part of the Eastern Mindanao Biodiversity Corridor (EMBC). EMBC is considered as one of the remaining intact forests in the country (Conservation International, 2016) and remains to be underexplored in terms of its odonata fauna. The only Odonata study conducted in Mt. Hamiguitan was made by Villanueva and Mohagan (2010) across the different vegetation types in the mountain of which a total of 31 species was recorded. No survey was done after that especially on the adjacent rivers in the buffer zone. This study aims to provide the list of Odonata found in the fluvial systems in the buffer zones of MHRWS as well as to document the distribution of the IUCN endangered Risiocnemis antoniea in Davao Oriental using GIS mapping. Since no Odonata study was conducted in the buffer zone, this study is crucial in supporting the move to expand the range of Mt. Hamiguitan. Mapping out the IUCN endangered Risiocnemis antoniea (Gassman and Hamalainen, 2002) will also provide critical data to the local government unit of Governor Generoso to consider its current distribution range as Local Conservation Area (LCA) though a municipal ordinance.

\section{Materials and Methods}

\section{Place and duration}

The study was conducted in the buffer zone of Mt. Hamiguitan Range Wildlife Sanctuary which comprises both agro-ecosystem and secondary forest. A $7 \mathrm{~km}$ transect walk was conducted in the fluvial systems of Brgy. TandangSora, Governor Generoso while a $2 \mathrm{~km}$ transect walk was conducted in Barangays La Union and Maputi, San Isidro, Barangay TandangSora, Governor Generoso, and Barangay Catmonan, Mati City between the months of September 2015 and January 2018.

\section{Collection and species mapping}

Collection of specimens was done by hand picking for low flying Zygopteran species and netting for the Anisopterans. To document the distribution of $R$. antoniae, a Global Positioning System (GPS) data of each site where the species were located was obtained using a handheld Garmin GPS Map 64S and GIS was created using Manifold System 8.0. Photo-documentation and visual encounter were also conducted to aid in data gathering.

\section{Identification and deposition}

Identification was done by examining the morphology of the Odonata species under stereomicroscope with the aid of published papers and Mindanao Odonata photo guide (Villanueva, 2011; Medina et al., 2016). Vouchered specimens are individually placed in paper triangle and properly labelled. Individual voucher collection is killed by immersing in the acetone for a few seconds and then properly positioned prior to soak for 24 hours in acetone. Materials were then air dried and placed again in individual paper triangle with collection label and placed in a sealed container for longer storage. Species richness was obtained using frequency count per barangay while endemism and geographic distribution of species were noted using IUCN Red List of Threatened Species (IUCN Red List, ver. 2017-3).

\section{Results and Discussion}

A total of 32 species from 22 genera and 9 families were recorded in which eighteen species (18) belong to the suborder Zygoptera while 14 species are Anisoptera. The 18 species of Zygoptera (Table 1) recorded belong to 12 genera and 7 families while 14 species of Anisoptera belonged to 10 genera and 2 families. A high level of endemism was recorded for Zygoptera with $94.44 \%$ endemism while low endemism was recorded for Anisoptera with 21.43\%. Seven (38.88\%) of the endemic Zygoptera are Philippine endemic, $8(44.44 \%)$ are Mindanao endemic while 2 (11.11\%) are Greater Mindanao endemic.

Zygoptera or commonly known as damselflies are low fliers with high habitat specificity as well as narrow geographic range. Endemic Zygoptera prefers pristine fluvial systems with good vegetation cover and they are sensitive to anthropogenic disturbances. They are often found in still waters and perch in twigs along the creeks and rivers. The high level of endemicty of damselflies in the buffer zone of Mt. Hamiguitan suggests that the remaining fluvial systems areas sampled have pristine waters and good vegetation cover.

Among the 7 families documented, Platycnemididae is the most speciose with 7 species recorded (38.88\%) followed by Coenagrionidae with 4 species (22.22\%). Chlorocyphidae and Platystictidae were represented by 2 species (11.11\%) while only one species $(5.55 \%)$ represents the families Calopterygidae, Euphaeidae, Megapodagrionidae.

One of the most notable species recorded in the buffer zone of Mt. Hamiguitan is the Mindanao endemic and threatened Risiocnemis antoniae belonging to the family Platycnemididae. This species was described from Aliwagwag Falls, Davao Oriental in 2002 and its distribution is restricted in Eastern Mindanao from Davao Oriental to Surigao. According to IUCN, 2017 this species is among the few assessed species of Philippine Odonata and is considered as critically endangered due to "the very narrow area of occupancy is aggravated by rapid increase of settlement of upland areas and conversion of forest habitat to farming land" (Villanueva, 2009). A project supported by Mohammed bin Zayed made the assessment of the population and distribution of Risiocnemis antoniae possible in Davao Oriental. This is deemed necessary to further protect this critically endangered damselfly that is at great risk of extinction due to habitat loss. This damselfly was recorded in TandangSora, Governor Generoso and Tumalite, San Isidro.

Among the three sites surveyed, fluvial system in Barangay Maputi has the highest species richness with 16 species $(88.88 \%)$ of Zygopteran followed by Brgy. TandangSora with 14 species $(77.77 \%)$ while Brgy. Tumalite has only $9(50 \%)$ species. The high species richness of Barangay Maputi is attributed to its semipristine and well vegetated fluvial system which catered to a high number of endemic and rare species viz Rhinagrion reinhardi (Kalkman and Villanueva, 2011), Euphaea amphicyana (Ris, 1930), Vestalis melania, Coellicia dinocerus (Laidlaw, 1925) among others. For Brgy. Tumalite, the presence of Risiocnemis antoniea and Pandanobasis cantuga 
16

(Fig. 1) (Needham and Gyger, 1939; Villanueva, 2002) are notable records. $P$. cantuga used to belong to the genus Amphicnemis but has been revised and named after the plant it inhabits - Pandanus sp. Members of this genus are phytothelmates which inhabits the waters found in pandan. Unlike most damselflies which are found near creek, Pandanobasis are found in forests with abundance of Pandanus spp.

Despite the unique Zygopteran composition in the 3 fluvial systems surveyed which can be attributed to the difference in vegetation cover and level of anthropogenic disturbances, some species are shared by the 3 areas which include Vestalis melania, Rhinocypha colorata, Rhinocypha turconii, Pseudagrion pilidorsum pilidorsum, Euphaea amphicyana, Prodasineura integra, and Risiocnemis appendiculata. One of the interesting species shared by Brgy. Maputi and Brgy. Tandang Sora belongs to the genus Drepanosticta, D. lestoides and D. fflavomaculata they were both documented in the fluvial systems of the two barangays. Drepanosticta are forest dwelling damselflies and sensitive to anthropogenic disturbances. Furthermore this taxon indicates relatively pristine fluvial systems in both barangays. Its taxonomy remains unresolved and needs further study.

Table 1.Zygopterans recorded in MHRWS, Davao Oriental Philippines

\begin{tabular}{|c|c|c|c|c|c|c|c|}
\hline \multirow{2}{*}{ Family } & \multirow{2}{*}{ Scientific name } & \multicolumn{4}{|c|}{ Sampling sites and habitat } & \multirow{2}{*}{ GD } & \multirow{2}{*}{ CS } \\
\hline & & A & B & $\mathrm{C}$ & $\mathrm{D}$ & & \\
\hline Calopterygidae & Vestalis melania Selys, 1873 & $\checkmark$ & $\checkmark$ & $\checkmark$ & $\checkmark$ & PE & $\mathrm{DD}$ \\
\hline \multirow{2}{*}{ Chlorocyphidae } & Rhinocypha colorata Hagen in Selys, 1869 & $\checkmark$ & $\checkmark$ & $\checkmark$ & $\checkmark$ & PE & DD \\
\hline & Rhinocypha turconii Selys, 1891 & $\checkmark$ & $\checkmark$ & $\checkmark$ & $\checkmark$ & PE & $\mathrm{DD}$ \\
\hline \multirow{4}{*}{ Coenagrionidae } & Coeriagrion lieftincki Asahina, 1967 & $\checkmark$ & & $\checkmark$ & & PE & DD \\
\hline & Pandanobasis cantuga (Needham and Gyger, 1939; Villanueva, 2002) & & $\checkmark$ & $\checkmark$ & & $\mathrm{PE}$ & $\mathrm{DD}$ \\
\hline & Pseudagrion pilidorsum pilidorsum Brauer, 1868 & $\checkmark$ & $\checkmark$ & $\checkmark$ & $\checkmark$ & $\mathrm{O}$ & DD \\
\hline & Teinobasis annamaijei Hamalainen\& Muller, 1989 & & $\checkmark$ & $\checkmark$ & & $\mathrm{PE}$ & DD \\
\hline \multirow{4}{*}{$\begin{array}{c}\text { Euphaeidae } \\
\text { Megapodagrionidae }\end{array}$} & Euphaea amphicyana Ris, 1930 & $\checkmark$ & $\checkmark$ & $\checkmark$ & $\checkmark$ & GME & DD \\
\hline & Rhinagrion reibnhardi Kalkman\& Villanueva, 2011 & & & $\checkmark$ & & ME & $\mathrm{DD}$ \\
\hline & Coellicia dinocerus Laidlaw, 1925 & $\checkmark$ & & $\checkmark$ & $\checkmark$ & GME & $\mathrm{DD}$ \\
\hline & Prodasineura integra Selys, 1882 & $\checkmark$ & $\checkmark$ & $\checkmark$ & $\checkmark$ & PE & DD \\
\hline \multirow{4}{*}{ Platycnemididae } & Risiocnemis appendiculata (Brauer, 1868) & $\checkmark$ & $\checkmark$ & $\checkmark$ & $\checkmark$ & ME & $\mathrm{DD}$ \\
\hline & Risiocnemis atripes Needham and Gyger, 1941 & $\checkmark$ & & $\checkmark$ & $\checkmark$ & ME & $\mathrm{DD}$ \\
\hline & Risiocnemis antoniae (Gassman and Hamalainen, 2002) & $\checkmark$ & $\checkmark$ & & & ME & $\mathrm{E}$ \\
\hline & Risiocnemis erythrura Brauer, 1868 & $\checkmark$ & & $\checkmark$ & $\checkmark$ & ME & DD \\
\hline \multirow{4}{*}{ Platystictidae } & Risiocnemis tendipes Needham and Gyger 1941 & $\checkmark$ & & $\checkmark$ & $\checkmark$ & ME & DD \\
\hline & Drepanosticta lestoides (Brauer, 1868) & & & $\checkmark$ & & ME & $\mathrm{DD}$ \\
\hline & Drepanosticta cf flavomaculata & $\checkmark$ & & & $\checkmark$ & ME & $\mathrm{DD}$ \\
\hline & Total & 14 & 10 & 16 & 12 & & \\
\hline
\end{tabular}

GD - Geographic Distribution; CS - Conservation Status; DD - Data Deficient; O - Oriental; A - Brgy. TandangSora, Governor Generoso; B - La Union, San Isidro; C - Brgy. Maputi, San Isidro; D - Catmonan, Mati City.

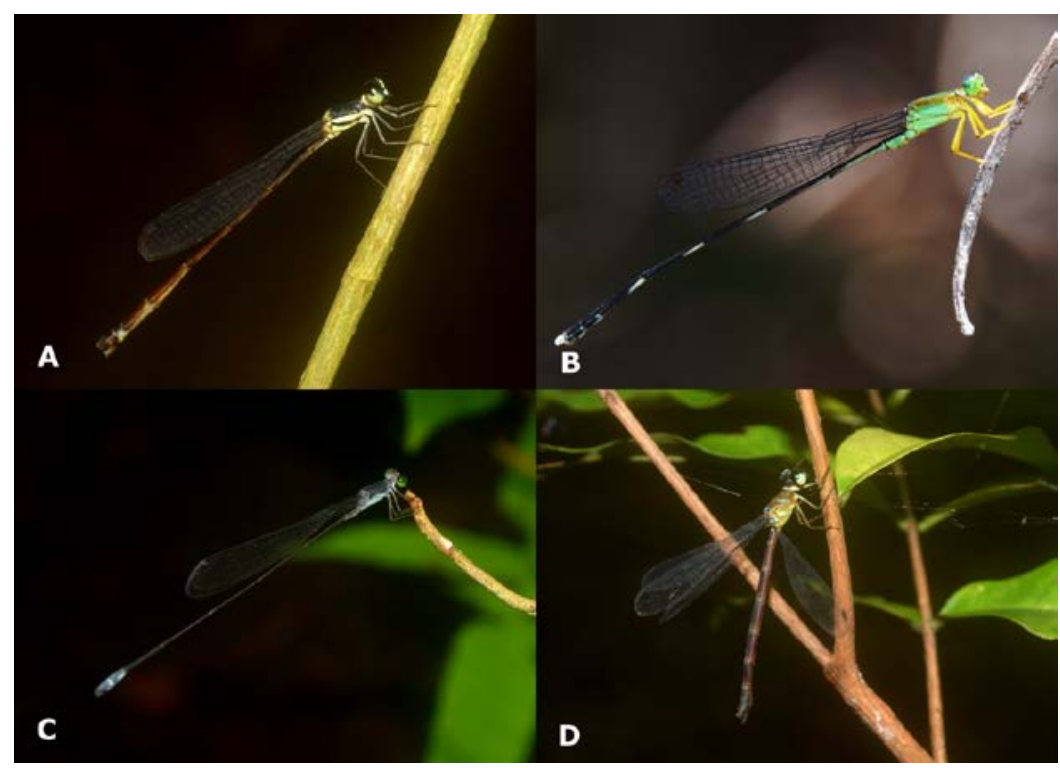

Fig. 1. A) Coellicia dinocerus (Laidlaw, 1925). B) Pandanobasis cantuga (Needham and Gyger, 1939; Villanueva, 2002). C) Teinobasis annamaijei (Hamalainen and Muller, 1989). D) Rhinagrion reihnhardi (Kalkman and Villanueva, 2011) 
A total of 14 Anisopterans (Table 2) were recorded in the buffer zone of Mt. Hamiguitan belonging to 10 genera and 2 families. A low level of endemism was recorded for Anisopterans with only three out of 14 (21.43\%) endemism. The three species recorded viz Idionyx philippa (Ris, 1912), Heteronias heterodoxa (Needham and Gyger, 1937), Diplacinabolivari (Selys, 1882) are all Philippine endemic while the rest are Oriental species. The fluvial systems surveyed were dominated by the family Libellulidae with 12 species $(85.71 \%)$ while Corduliidae was only represented by 2 species (14.29\%). The family Libellulidae were surveyed in fluvial systems which are open with mild anthropogenic disturbances while the members of the family Corduliidae were documented in areas with pristine waters and heavy vegetation. Libellulidae species favors open standing waters and can highly tolerate moderate to severe anthropogenic disturbances (Kalkman et al., 2008). In the three surveyed sites, they were often spotted near agroecosystems. One particular species - Pantala flavescens from the family Libillulidae is considered invasive species.

Among the sites surveyed, Bgry. Maputi is still the most speciose with 13 (92.86\%) species followed by TandangSora with 12 species (85.71\%), Brgy. Catmonan with 11 (73.33\%) and Bgry. Tumalite with only 7 species (50\%). Tandang Sora, Maputi and Catmonan shared Philippine endemic species includes $H$. heterodoxa (Needham and Gyger, 1937) and D. bolivari (Selys, 1882). Moreover, I. philippa, another Philippine endemic species, was recorded only in Brgy. Maputi while L. cleis was recorded only in Brgy. Tumalite (Fig. 2).

Table 2. Anisopteransrecorded in MHRWS, Davao Oriental Philippines

\begin{tabular}{|c|c|c|c|c|c|c|c|}
\hline \multirow{2}{*}{ Family } & \multirow{2}{*}{ Scientific name } & \multicolumn{4}{|c|}{ Sampling sites } & \multirow{2}{*}{ GD } & \multirow{2}{*}{ CS } \\
\hline & & A & B & $\mathrm{C}$ & $\mathrm{D}$ & & \\
\hline \multirow[t]{7}{*}{ Corduliidae } & Idionyx philippa Ris, 1912 & & & $\checkmark$ & $\checkmark$ & $\mathrm{PE}$ & $\mathrm{DD}$ \\
\hline & Heteronia sheterodoxa Needham and Gyger, 1937 & $\checkmark$ & & $\checkmark$ & $\checkmark$ & $\mathrm{PE}$ & DD \\
\hline & Agrionoptera insignis Rambur 1842 & $\checkmark$ & & $\checkmark$ & $\checkmark$ & $\mathrm{O}$ & $\mathrm{DD}$ \\
\hline & Diplacina bolivari Selys, 1882 & $\checkmark$ & & $\checkmark$ & $\checkmark$ & PE & DD \\
\hline & Diplacodes trivialis Rambur 1842 & $\checkmark$ & $\checkmark$ & $\checkmark$ & & $\mathrm{O}$ & $\mathrm{DD}$ \\
\hline & Lyriothemis cleis (Brauer 1868) & $\checkmark$ & $\checkmark$ & & & $\mathrm{O}$ & $\mathrm{DD}$ \\
\hline & Neurothemis ramburii Brauer, 1866 & $\checkmark$ & & $\checkmark$ & $\checkmark$ & $\mathrm{O}$ & DD \\
\hline \multirow[t]{8}{*}{ Libellulidae } & Neurothemis terminata Ris, 1911 & $\checkmark$ & $\checkmark$ & $\checkmark$ & $\checkmark$ & $\mathrm{O}$ & DD \\
\hline & Orthetrum pruinosum clelia Selys, 1878 & $\checkmark$ & $\checkmark$ & $\checkmark$ & $\checkmark$ & $\mathrm{O}$ & $\mathrm{DD}$ \\
\hline & Orthetrum testaceum (Burmeister, 1839) & $\checkmark$ & & $\checkmark$ & $\checkmark$ & $\mathrm{O}$ & $\mathrm{DD}$ \\
\hline & Orthetrum sabina sabina (Drury 1770) & $\checkmark$ & $\checkmark$ & $\checkmark$ & & $\mathrm{O}$ & DD \\
\hline & Pantala flavescens Fabricus 1798 & $\checkmark$ & $\checkmark$ & & $\checkmark$ & CT & DD \\
\hline & Trithemis aurora (Burmeister 1839) & $\checkmark$ & $\checkmark$ & $\checkmark$ & $\checkmark$ & $\mathrm{O}$ & $\mathrm{DD}$ \\
\hline & Trithemis festiva (Rambur 1842) & $\checkmark$ & & $\checkmark$ & $\checkmark$ & $\mathrm{O}$ & DD \\
\hline & TOTAL & 13 & 7 & 12 & 11 & & \\
\hline
\end{tabular}

GD - Geographic Distribution; CS - Conservation Status; DD - Data Deficient; O - Oriental; A - Brgy. TandangSora, Governor Generoso; B - La Union, San Isidro; C - Broy. Maputi, San Isidro; D - Catmonan, Mati City.

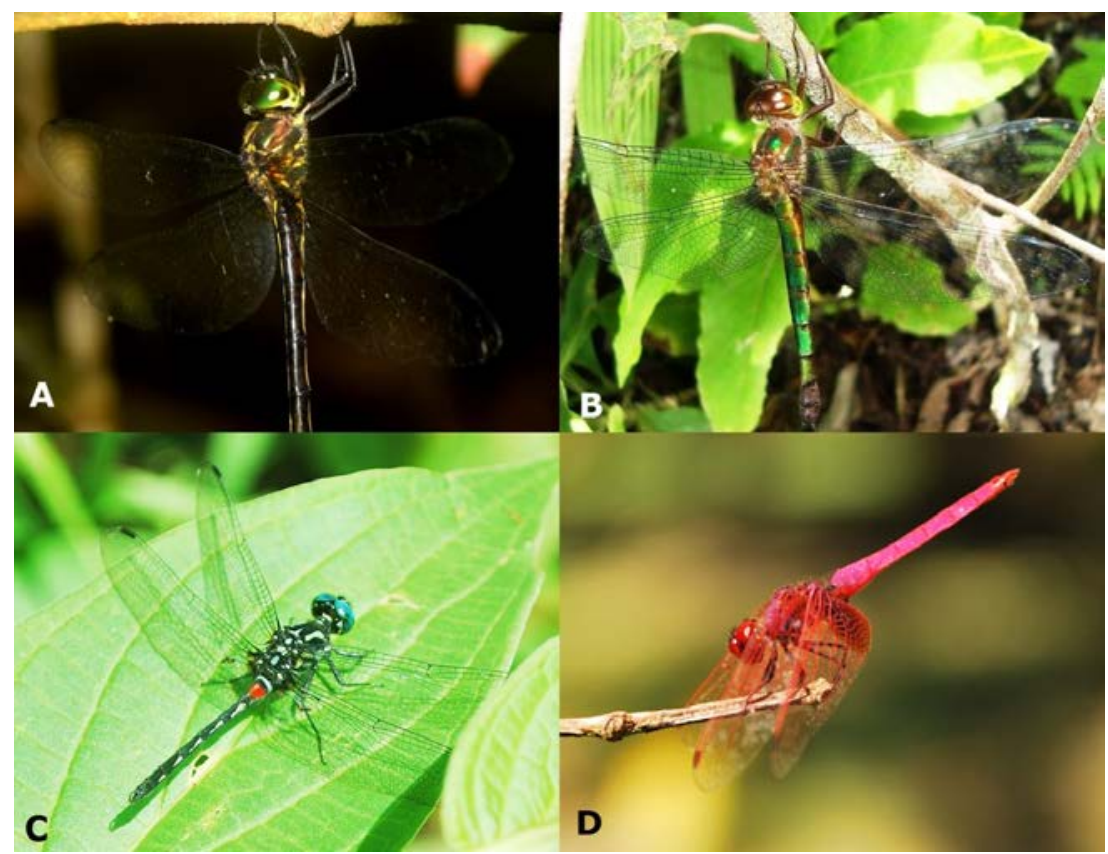

Fig. 2. A) Idionyx philippa (Ris, 1912). B) Heteronias heterodoxa (Needham and Gyger, 1937). C) Diplacina bolivari (Selys, 1882).

D) Trithemis aurora (Burmeister 1839) 
18

L. cleis is a phytothelmate species together with the damselfly $P$. cantuga recorded from Mt. Hamiguitan. This species breeds in water filled tree holes, depressions in fallen tree trunks and small pools on the forest floor and has been observed to be capable of withstanding mild forest disturbance (R. Dow, pers. comm., 2010). All Anisopteran species are data deficient based on IUCN Red List of Threatened species (IUCN, 2017-3).

\section{Distribution of $R$. antoniae}

The recent distribution of $R$. antoniae in TandangSora is found nearby local communities. As shown in Fig. 3, majority of the population is found along the river bank of Barangay Tandang Sora, Governor Generoso at relatively lower elevation between 100-300 meters above sea level, hence making the location very accessible to local villagers.

At present, there is no conservation effort exerted to conserve $R$. antoniae. Considering the vulnerability of the species to human anthropogenic activities since it is very close to settlements, there is a greater tendency for its population to decline in the next years.

Some of the population is located outside the boundary of the Protected Area thereby calling for immediate conservation efforts. For two years of documentation within the area, a total of 114 individuals consisting of 112 males and only 2 females were recorded. In 2017, one male was sighted near the interpretation site of MHRWS. With this, we are proposing to raise the protection status of $R$. antoniae (Fig. 4) to critically endangered species in the IUCN.

The urgent concern for this species is the very rare occurrence of females. For approximately 2 years of monitoring in the area, only 2 females are found. This poses greater threat to their extinction. Hence urgent conservation efforts are greatly needed to conserve $R$. antoniae.

\section{Conclusions}

The fluvial systems of the buffer zone of MHRWS host high species richness and endemism especially for Zygopterans. Odonates highest diversity is in forests edges due to the habitats suited for both endemic and highly sensitive forest dwelling species to the highly tolerant and widely distributed Oriental species which inhabits disturbed and agro-ecosystems. The high level of endemism indicates that its fluvial systems are still pristine and have good vegetation that suits the habitat requirements of the endemic species. The presence of the rare, endemic and critically endangered $R$. antoniae requires an immediate conservation action on the habitats where they were found. Monitoring and population assessment of the other lesser known endemic species should be conducted to strengthen conservation actions.

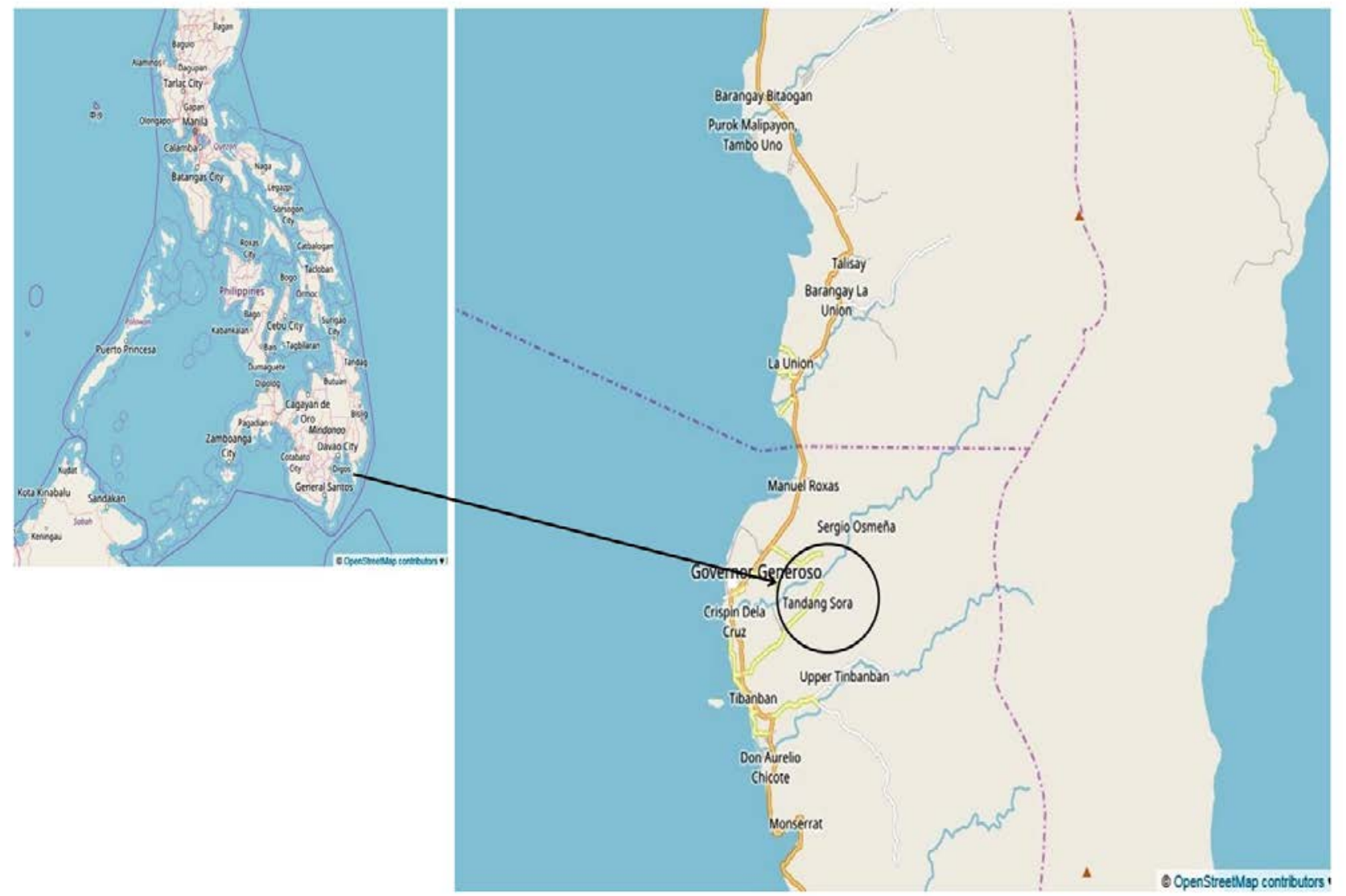

Fig. 3 A. Map of the Philippines; B. Map of Mt. Hamiguitan Range Wildlife Sanctuary showing the location of R. antoniae [Map copyright by (C) OpenStreetMap contributor] 


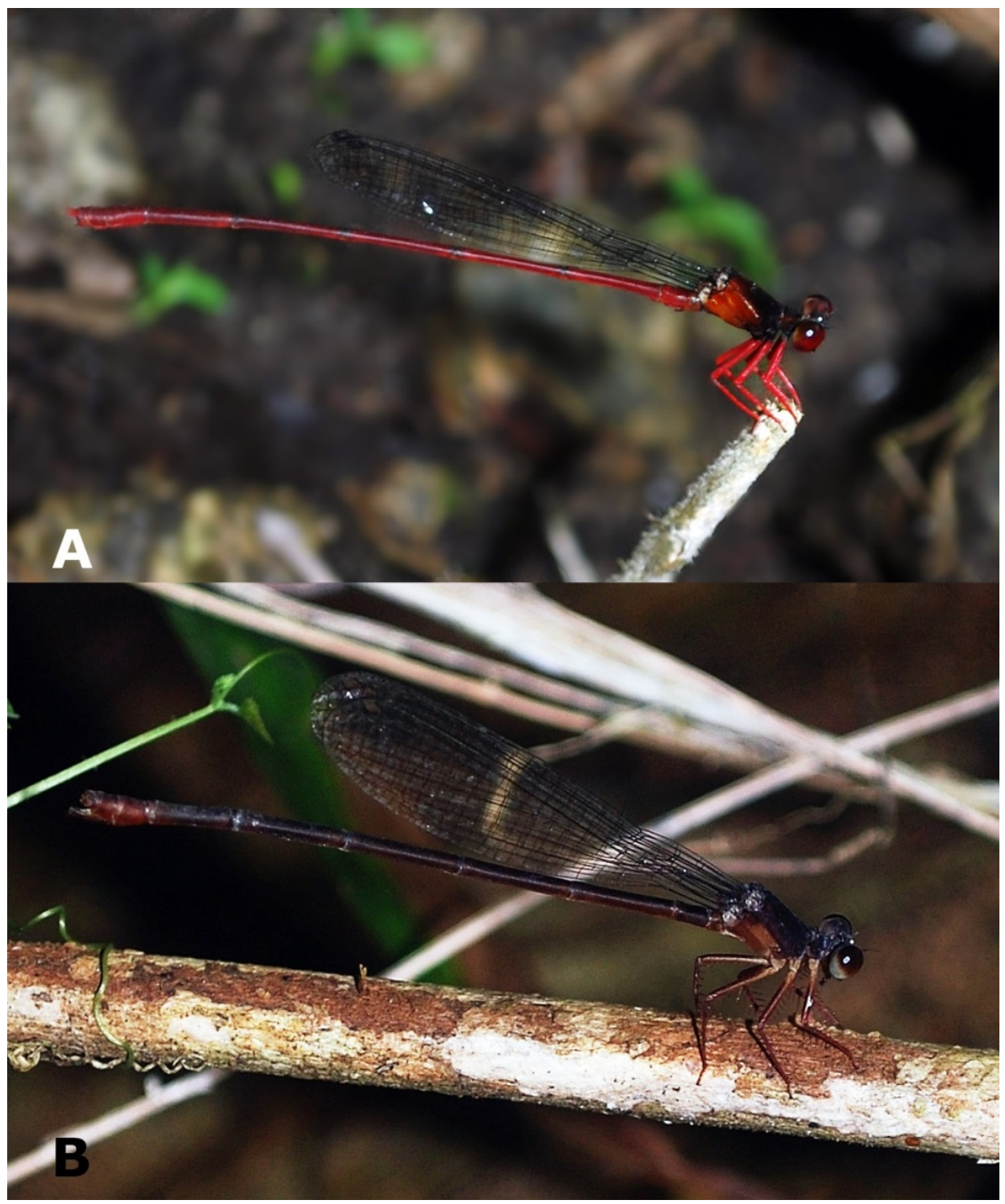

Fig. 4. A. Risiocnemis antoniae - male (Gassman and Hamalainen, 2002); B. Risiocnemis antoniae - female (Gassman and Hamalainen, 2002)

\section{Acknowledgements}

This work was supported by the Mohammed bin Zayed Species Conservation Fund grant number 162512210. Our gratitude to the MHRWS PASu technical personnel for the assistance during fieldwork namely, Felipe Gorme, Emee Grace Daquiado, Gypsy Ogahayon, Alfredo 'TatayPidoy' Bolante Sr., Braulio Matigaldao, Mr. RemeLipay, Leonido Clarion, Alfredo Bolante Jr., Jerry Boy Torlon, Valentine Jimenez Jr.; Members of the LGU La Union, Eric Dave Mendoza and John Mheler Vergara; Research Assistant Kim Jumawan \& Niel Balbon; People of Eco Catmonan in Mati City; Dr. Roy Ponce and Daruel Porlares during visit in Catmonan.

\section{References}

Catibog-Sinha CS, Heaney LR (2006). Philippine biodiversity: Principles and practice. Quezon City: Haribon Foundation for the Conservation of Natural Resources, Inc.
Convention on Biological Diversity (2009). Assessing progress towards the 2010 biodiversity target: the 4th national report to the convention on biological diversity. Convention on Biological Diversity. Retrieved 2018 March 4 from https://www.cbd.int/doc/world/ph/ph-nr-04-en.pdf.

Conservation International (2016). Biological importance. Critical Ecosystem Partnership Fund. Retreived 2018 March 4 from http://sp13.cepfnet/where_we_work/regions/asia_pacific/philippines /ecosystem_profile/Pages/biological_importance.aspx.

Dow RA, Subramanian KA (2010). Lyriothemiscleis. The IUCN Red List of Threatened Species 2010: e.T169092A6563627. Retrieved 2017 March 18 from http://dx.doi.org/ 10.2305/IUCN.UK.20104.RLTS.T169092A6563627.en.

Gapud V (2005). The status of insect biodiversity in the Philippines. SamutSaripp 2-5.

Gassmann D, Hämäläinen M (2002). A revision of the Philippine subgenus Risiocnemis (Igneocnemis) Hämäläinen (Odonata: Platycnemididae). 
20

Entomologie 145:213-266.

Grimaldi D, Engel MS (2005). Evolution of the insects. Cambridge University Press, New York.

Hamalainen M, Muller RA (1997). Synopsis of the Philippine Odonata with list of species recorded from forty islands. Odontology 26(3):249315.

Hämäläinen M (2012). Critical species of Odonata in the Philippines, International Journal ofOdonatology 7(2):305-310.

Heaney LR, Regalado JC (1998). Vanishing treasures of the Philippine rain forest. The Field Museum, Chicago, Illinois, USA.

IUCN (2017). IUCN Redlist of Threatened Species, version 2017-3. Retrieved 2017Nov 4from http://www.iucnredlist.org.

Kalkman V, Clausnitzer V, Dijkstra K, Orr A, Paulson D, Tol J (2008). Global diversity of dragonflies (Odonata) in freshwater: Freshwater animal diversity assessment. Hydrobiologia 595(1):351-363.

Medina MND, Cabras AA, Villanueva RJT (2016). Alindanaw, Davao City: University of Mindanao Research and Publication Center and Nagao Natural Environment Foundation.

Samways MJ, McGeoch, New TR (2010). Insect conservation: A handbook of approaches and methods. Oxford University Press, Oxfordpp 441 .
Silva DP,De Marco P, ResendeDC (2010). Adult Odonate abundance and community assemblage measures as indicators of stream ecological integrity: a case study. Ecological Indicators 10:744752.

UNESCO (2014). Mt. Hamiguitan Range Wildlife Sanctuary. United Nations Educational, Scientific and Cultural Organization. Retrieved 2018 March 4 from http://whc.unesco.org/en/list/1403.

Villanueva RJT (2011). Odonata fauna of Diomabok Lake and its surroundings. Davao Oriental, Mindanao Island, Philippines. International Dragonfly Fund Report 38:1-29.

Villanueva RJT, Mohagan A (2009). Diversity and status of Odonata across vegetation types in Mt. Hamiguitan Wildlife Sanctuary, Davao Oriental. Asian Journal for Biodiversity 1(1):25-35.

Villanueva RJT (2009). Risiocnemisantoniae. The IUCN Red List of Threatened Species 2009: e.T169294A6608127. Retrieved 2017 Dec4 from http://dx.doi.org/ 10.2305/IUCN.UK.20092.RLTS.T169294A6608127.en. 